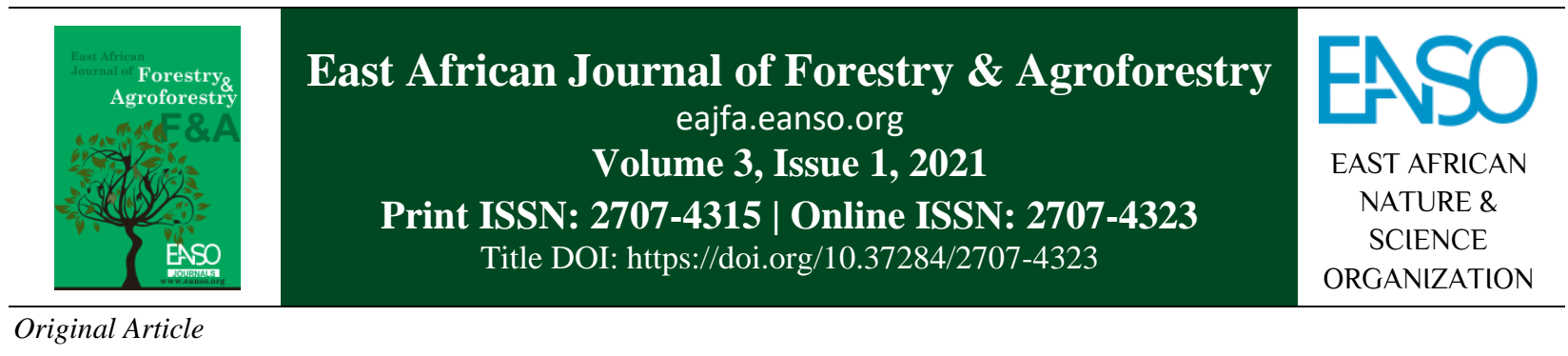

\title{
Incidence of Pests and Diseases in Tree Nurseries and Plantations in Kimondi Forest, Nandi County, Kenya
}

Joseph Atanga Ondieki ${ }^{1 *}$, Dr. Peter Sirmah $(P h . D)^{2}, \&$ Dr. Joseph Hitimana $(P h . D)^{3}$

${ }^{1}$ Department of Agroforestry, Environmental Studies and Integrated Natural Resource Management, University of Kabianga,

P. O. Box 2030-20200, Kericho, Kenya.

* ORCID: https://orcid.org/0000-0002-6619-5870; Author for Correspondence email: psirmah@kabianga.ac.ke.

Article DOI: https://doi.org/10.37284/eajfa.3.1.287

\section{Date Published: ABSTRACT}

05 March 2021 Increasing demand for wood is putting pressure on forest resources that are equally under threat from insect pests and diseases. Reported average annual

Keywords: forest loss stands at $0.2 \%$ globally, $0.8 \%$ in Africa, and $1.6 \%$ in Kenya. To meet the increasing demand for forest products in Kenya, the government and private

Pests, sector have established plantations of non-native tree species dominated by

diseases, Eucalyptus species, Cupressus lusitanica, and Pinus patula. To ensure tree nurseries,

plantations,

Kimondi forest, successful forest plantation establishment and management schemes, there is a need for sufficient knowledge and understanding of tree growth conditions and

Kenya. threats including pests and diseases. This study aimed at determining the incidence of plantation and tree nurseries in Kimondi Forest, Kenya. Tree plantations were mapped into $2.5 \mathrm{Ha}$ rectangular portion transects parallel to the forest roads. In randomly selected portions, observations were carried out for disease and pest signs and symptoms on various tree parts (leaves, stem, roots, fruits, and twigs). In the tree nurseries, $3 \mathrm{~m} \times 1 \mathrm{~m}$ rectangular quadrants were placed on seedling beds and similar observations were made. Collected data indicated a high incidence of nursery seedling pests $(5.3 \%$ leaves and $5.1 \%$ stems) on Eucalyptus species and least on P. patula (2.4\% leaves and 3\% stems). Higher incidence of plantation pests (35.0\% leaves of Eucalyptus sps.) and least on $P$. patula stems (1.2\%) were recorded. On the other hand, twelve (12.0\%) of C. lusitanica and (1.8\%) Eucalyptus species plantation twigs were infested by pests. A high incidence of nursery seedling disease $(9.8 \%)$ was observed on C. lusitanica leaves and least on P. patula stems (3.6\%). Higher incidence of plantation diseases (32\%) on leaves of Eucalyptus sps. and least on C. lusitanica stem (1.4\%) was recorded. In both tree nurseries and plantations, roots and fruits remained free from pests and disease. Major tree 
pests and diseases identified in Kimondi forests include (Human, wildlife, livestock, Cinara cupressi, Gonipterus scutellatus, Pinus pini, and Leptocybe invasa) and (damping-off, Fusarium wilt, Botryosphaeria canker, cypress canker, and Mycosphaerella spp.) respectively. These results suggest a need for regular monitoring and intervention measures to control pest and disease infestation in the Kimondi forest.

\begin{abstract}
APA CITATION
Ondieki, J. A., Sirmah, P., Hitimana, J. (2021). Incidence of Pests and Diseases in Tree Nurseries and Plantations in Kimondi Forest, Nandi County, Kenya East African Journal of Forestry and Agroforestry, 3(1), 18-28. https://doi.org/10.37284/eajfa.3.1.287

\section{CHICAGO CITATION}

Ondieki, Joseph Atanga, Peter Sirmah, Joseph Hitimana. 2021. "Incidence of Pests and Diseases in Tree Nurseries and Plantations in Kimondi Forest, Nandi County, Kenya". East African Journal of Forestry and Agroforestry 3 (1), 18-28. https://doi.org/10.37284/eajfa.3.1.287.
\end{abstract}

\title{
HARVARD CITATION
}

Ondieki, J. A., Sirmah, P., Hitimana, J. (2021) "Incidence of Pests and Diseases in Tree Nurseries and Plantations in Kimondi Forest, Nandi County, Kenya", East African Journal of Forestry and Agroforestry, 3(1), pp. 18-28. doi: 10.37284/eajfa.3.1.287.

\section{IEEE CITATION}

J. A. Ondieki, P. Sirmah, J. Hitimana, , "Incidence of Pests and Diseases in Tree Nurseries and Plantations in Kimondi Forest, Nandi County, Kenya", EAJFA, vol. 3, no. 1, pp. 18-28, Mar. 2021.

\section{MLA CITATION}

Ondieki, Joseph Atanga, Peter Sirmah, Joseph Hitimana. "Incidence of Pests and Diseases in Tree Nurseries and Plantations in Kimondi Forest, Nandi County, Kenya”. East African Journal of Forestry and Agroforestry, Vol. 3, no. 1, Mar. 2021, pp. 1828, doi:10.37284/eajfa.3.1.287.

\section{INTRODUCTION}

Increasing demand for wood and wood products has exerted pressure on natural forest resources throughout the world (FAO, 2007). These resources are currently under threat due to other factors including clearing forest land for agricultural production or settlements. According to FAO (2007), the world average annual forest losses stand at $0.2 \%$, while that of Africa is about $0.8 \%$.

The need to accommodate the increasing demand for tree products such as fibre and wood in Africa has therefore led to an increasing establishment of forest plantations using non-native tree species such as Eucalyptus, Cupressus lusitanica and Pinus patula species (Evans, 1992). These plantations have an important economic and social bearing for several countries in Africa providing a source of employment, wealth creation, the production of export capital as well as fuel and construction timber (FAO, 2007). Despite their importance, forest plantations using non-native species (exotic) are fragile and face unique threats mostly from pests and disease (Wingfield et al., 2001; Cock, 2003) due to a limited genetic base (Wingfield et al., 2008). Documented examples of major disease outbreaks in the history of forest plantations include Dothistroma needle blight of Pinus species in Chile, New Zealand and Kenya (Gibson, 1975); Phytophthora pinifolia in Chile (Durán et al., 2008); conifer aphid (Cinara cuppressivora) on Cupressus species in Eastern and Central Africa (Murphy, 1998; Day et al., 2003); the sirex wood wasp (Sirex noctilio) on Pinus species in South Africa (Tribe, 2003; Hurley et al., 2007), and the blue gum chalcid (Leptocybe invasa) on Eucalyptus species in many countries in Africa, Asia, the Middle East and Europe (Mutitu, 2003; Mendel et al., 2004; Nyeko, 2005; EPPO, 2006). Dothistroma septosporum led to the termination of $P$. radiata planting in many African countries, particularly those in East Africa (Gibson et al., 1964; Barnes et al., 2004). Similarly, the susceptibility of Eucalyptus to the snout beetle, Gonipterus scutellatus and Mycosphaerella leaf disease led to the partially discontinued planting of 
this species in South Africa (Lundquist et al., 1987). The afforestation examples illustrate how forest pests and diseases raise serious concerns to developers of tropical tree plantation enterprises. Unfortunately, FAO observed that many people working with trees do not pay systematic attention to tree health until trees have died and it is too late for intervention (FAO, 2003).

Outbreaks of serious pests and diseases may still be a major threat to future plantation development in Kenya. Example devastating outbreaks of Psyllid, Heteropsylla cubana in plantations of Leucaena leucocephala in South East Asia, conifer aphids in plantations in East Africa and eucalyptus leaf diseases are only recent history (Nair, 2000).

In order to contain pest and pathogen problems, there is a need for knowledge and information regarding the occurrence of nursery and plantation insect pests and diseases. This study aimed at evaluating the incidence of pests and diseases of tree nurseries and plantations of Kimondi Forest, Nandi County, Kenya.

\section{RESEARCH METHODOLOGY}

\section{Study Area}

This study was carried out in the Kimondi forest located in Nandi County, Kenya (Figure 1). It lies on latitude $0^{\circ} 18^{\prime}$ and $0^{\circ} 32^{\prime} \mathrm{N}$ and longitude $37^{\circ} 05^{\prime}$ to $37^{\circ} 23^{\prime}$ E in the North Rift Conservancy. The soils are characterized as very shallow to deep and dark yellowish-brown to very dark brown, respectively. Soil types range from friable sandy loam to sandy clay loam and friable gravelly sandy clay loam to sand clay with $5-50 \%$ fine to medium iron and manganese concentrations (Otieno et al., 2014)).

\section{Figure 1: Map of the Study Area}

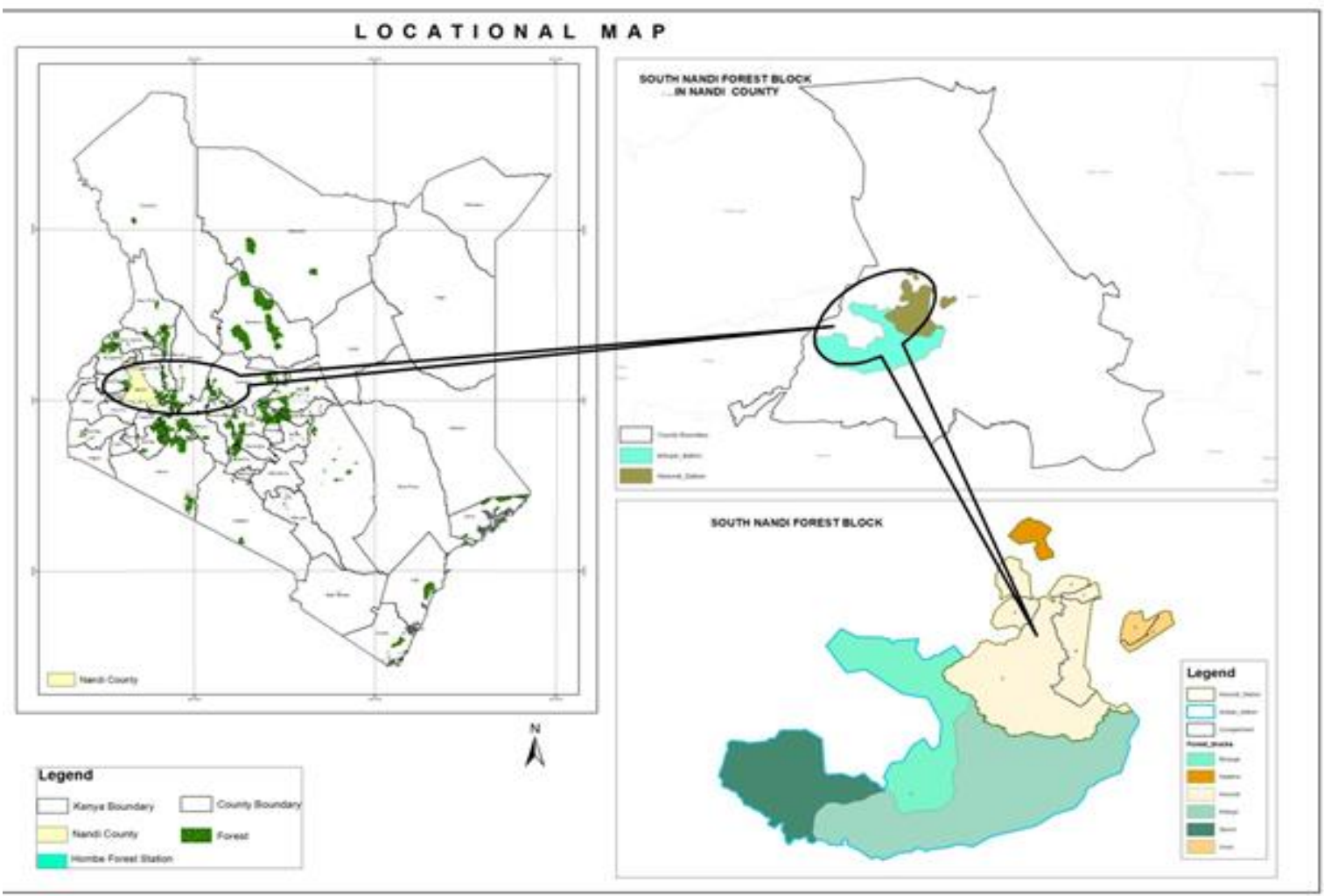

Source: Adopted from KFS. 
The Kimondi forest is mainly drained by both Kimondi and Sirua rivers which merge further downstream to form River Yala that finally flows into Lake Victoria (Mitchell, 2004). The forest is the source of water for the recently inaugurated Nzoia cluster II water project (supplies water to Kakamega town and its surroundings) and the Kobujoi water supply project (supplies water to Kobujoi and its surrounding) (Simon et al., 2016). Other rivers that drain water out of the Kimondi forest include Mokong, Orobo, Kundos, Gorgor, Chemogonja and Cheptaburbur. These rivers are perennial and therefore provide water for domestic and industrial use by the adjacent forest communities as well as have waterfalls, which can be harnessed for hydroelectric power generation (District Development Plan, Nandi South 2008-2012, GoK, 2008).

\section{Target Population}

The study targeted pests and diseases in both tree nursery seedlings and plantation species of Cupressus lusitanica (678.3 Ha), Pinus patula (147.5 Ha) and Eucalyptus species (48.8 Ha).

\section{Sampling in Tree Nurseries}

Tree seedlings within 10 portions of size $3 \mathrm{~m} \times 1 \mathrm{~m}$ were sampled for this study according to Sokal and Rohlf (2012) as follows: Nursery beds of the three tree species $(C$. lusitanica, $P$. patula, and Eucalyptus species) were separately divided into equal portions of $3 \mathrm{~m}$ by $1 \mathrm{~m}$ along the nursery lengths. Each portion was numbered; then, 10 portions were randomly selected for the purpose of this study. Incidence of nursery pests and diseases were observed on the roots, leaves and stems of the seedlings within each portion.

\section{Sampling in the Forest Plantations}

The targeted plantations (Eucalyptus, C. lusitanica and $P$. patula) were separately mapped into $2.5 \mathrm{Ha}$ rectangular plots (Figure 2). The plots were positioned in such a way that its long axis ran parallel with the planting rows.
Figure 2: Configuration of the 2.5 Ha Sample Plot Within a Plantation

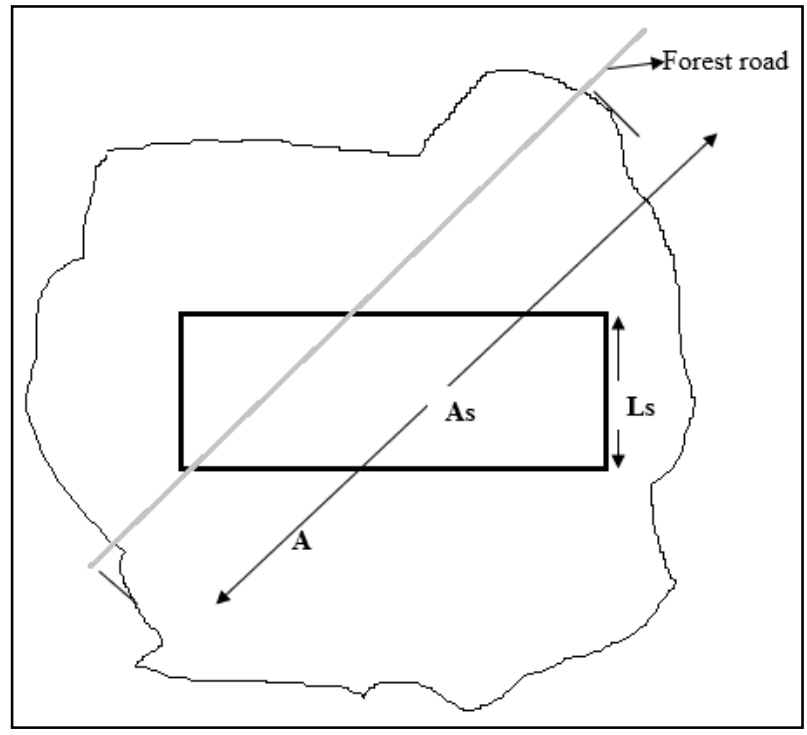

The ratio of the length of road within the compartment (L) to the compartment area (A) was the same as the length of road (Ls) within the $2.5 \mathrm{Ha}$ sample area (As).

Ground line transect walk was carried out along the road and a take-off point was randomly chosen along the distance abutting each of the $2.5 \mathrm{Ha}$ sample plots per plantation species. Observations were made on 20 consecutive trees for incidences of pests and disease incursion. Across several rows, a further 20 consecutive trees were inspected for damage on the return journey to the road.

\section{Determination of Diseases and Pests Incidence}

In each sampled portion (nursery beds or plantations) number of diseased and pest-infested roots, leaves, fruits, twigs and stems were recorded separately and expressed as the proportion of total number in each set respectively according to Anonymous (2006) as follows:

Leaf incidences $(\%)=$

$\frac{\text { Number of infected leaves }}{\text { Total leaves observed in a portion }}$ X 100 .

Fruit incidence $(\%)=$ Number of infected fruits

$\overline{\text { Total fruits observed in a portion }}$ X 100 
East African Journal of Forestry and Agroforestry, Volume 3, Issue 1, 2021

Article DOI: https://doi.org/10.37284/eajfa.3.1.287

Twigs incidences $(\%)=$

$\frac{\text { Number of infected twigs }}{\text { Total twigs observed in a portion }} \times 100$

Root incidences $(\%)=$

$\frac{\text { Number of infected leaves }}{\text { Total leaves observed in a portion }} \times 100$

Stem incidences $(\%)=$

$\frac{\text { Number of infected leaves }}{\text { Total leaves observed in a portion }}$ X 100

Photographs of pest and disease-infested plant parts were taken and used for identification purposes.

\section{RESULTS AND DISCUSSION}

Incidence of Tree Nursery and Plantation Pests

Table 1 reports the incidence of nursery pests in Kimondi forest tree nurseries. Five $(5.3 \%)$ of Eucalyptus leaves were damaged by pests in comparison with $4.7 \%$ in C. lusitanica and $2.4 \%$ in
P. patula. Roots for all the seedlings were free from pests.

Table 1: Incidence of Tree Nursery Pests

\begin{tabular}{llll}
\hline Species & \multicolumn{3}{l}{$(\%)$ Incidence of Pests } \\
\cline { 2 - 4 } & Leaves & Stems & Roots \\
P. patula & 2.4 & 3.0 & 0.0 \\
C. lusitanica & 4.7 & 5.0 & 0.0 \\
Eucalyptus & 5.3 & 5.2 & 0.0 \\
\hline
\end{tabular}

Table 2 reports the incidence of pests in the Kimondi forest plantation. Thirty-Five per cent $(35 \%)$ of Eucalyptus leaves were damaged by pests in comparison with $11.5 \%$ in C. lusitanica and 9.6 $\%$ in $P$. patula. Twelve per cent $(12 \%)$ of $C$. lusitanica twigs were damaged by pests in comparison to a lower margin (1.8\%) observed in Eucalyptus species. Fruits for all the tree species were free from pests.

Table 2: Incidence of Forest Plantation Pests

\begin{tabular}{lllll}
\hline Species & \multicolumn{3}{l}{ \% Incidence of Pests } & \\
\cline { 2 - 5 } & Leaves & Stem & Twigs & Fruits \\
P. patula & 9.6 & 1.2 & 8.1 & 0.0 \\
C. lusitanica & 11.5 & 1.3 & 12.0 & 0.0 \\
Eucalyptus species & 35.0 & 5.6 & 1.8 & 0.0 \\
\hline
\end{tabular}

Minor pest attack on Eucalyptus (5.6\%), P. patula $(1.3 \%)$ and $C$. lusitanica (1.2\%) stems were observed. These results suggest that leaves of both the tree nurseries and plantation species are mainly targeted by pests in comparison to the stems, fruits and roots. Such observation has been reported in other similar studies (Nsolomo \& Venn, 1984); Nyeko \& Nakabonge, 2008; Wingfield et al., 2010).

Table 3: Incidence of Tree Nursery Diseases

\section{Incidence of Tree Nursery and Plantation Diseases}

Table 3 reports the incidence of diseases in Kimondi forest tree nurseries. $9.8 \%$ of $C$. lusitanica leaves were damaged by diseases in comparison with $8.0 \%$ in P. patula and $5.6 \%$ in Eucalyptus tree species.

\begin{tabular}{llll}
\hline Species & \multicolumn{3}{l}{ (\%) Incidence of Diseases } \\
\cline { 2 - 3 } & Leaves & Stems & Roots \\
P. patula & 8.0 & 5.1 & 0.0 \\
C. lusitanica & 9.8 & 3.6 & 0.0 \\
Eucalyptus species & 5.6 & 7.7 & 0.0 \\
\hline
\end{tabular}

Based on Table 3, 7.7\% of Eucalyptus species stems were damaged by diseases in comparison to $3.6 \%$ observed in C. lusitanica and $5.1 \%$ in P. patula. Roots of all tree seedling species remained free from 
diseases. Such observations have been reported in other similar studies (Gichora et al., 2017).

Table 4 reports the incidence of diseases in the Kimondi forest plantation. Thirty-Five (32\%) of Eucalyptus leaves were damaged by pests in comparison with $12 \%$ in C. lusitanica and $21 \%$ in
P. patula. Fourteen (14.6\%) of C. lusitanica twigs were damaged by pests in comparison to a higher margin (17\%) observed in Eucalyptus species. Fruits for all the tree species were free from pests, while minimal damage on stems $(8.5 \%)$ on Eucalyptus species, (1.4\%) on C. lusitanica and $3.2 \%$ on $P$. patula was observed.

Table 4: Incidence of Forest Plantation Diseases

\begin{tabular}{lllll}
\hline Species & \multicolumn{3}{l}{ (\%) Incidences of Diseases } & \\
\cline { 2 - 4 } & Leaves & Stem & Twigs & Fruits \\
P. patula & 21.3 & 3.2 & 7.8 & 0.0 \\
C. lusitanica & 12.0 & 1.4 & 17.7 & 0.0 \\
Eucalyptus species & 32.0 & 8.5 & 14.6 & 0.0 \\
\hline
\end{tabular}

\section{Major Pests and Diseases in Kimondi Forest}

Table 5 reports the major pests identified in the Kimondi forest. Leptocybe invasa was observed on young seedlings of Eucalyptus species in the nursery (Plate $1 a \& b$ ) as small circular galls on the midribs of the leaves. Leptocybe invasa lays eggs on the bark of shoots or the midribs of leaves; eggs develop into the minute, white, legless larvae within the host plant.

Table 5: Major Pests Identified in Kimondi Forest

\begin{tabular}{|c|c|c|}
\hline Pest & Observed Symptoms & Affected Tree Species \\
\hline Leptocybe invasa & Pinhole on leaves, galls on mid-ribs and petioles & Eucalyptus leaves \\
\hline Termites & $\begin{array}{l}\text { Nearby termite mounds, stems debarked at the base } \\
\text { of the plant }\end{array}$ & All species \\
\hline Livestock/wildlife & $\begin{array}{l}\text { De-budding, cut stems and branches, debarking, } \\
\text { browsings on leaves }\end{array}$ & All species \\
\hline Pinus pini & Defoliation, dieback, needle shading, dead trunks & Pinus patula \\
\hline $\begin{array}{l}\text { Gonipterus } \\
\text { scutellatus }\end{array}$ & $\begin{array}{l}\text { Leaf defoliation, scalloped leaf edges, dieback of } \\
\text { shoot tips }\end{array}$ & Eucalyptus \\
\hline Cinera cupressi & Galls & Cupressus lusitanica \\
\hline Human & Logging, debarking, cuttings, uprooting & All species \\
\hline
\end{tabular}


Plate 1: a)Galls of Leptocybe invasa on Eucalyptus Leaves; b) Debarked P. Patula Stem

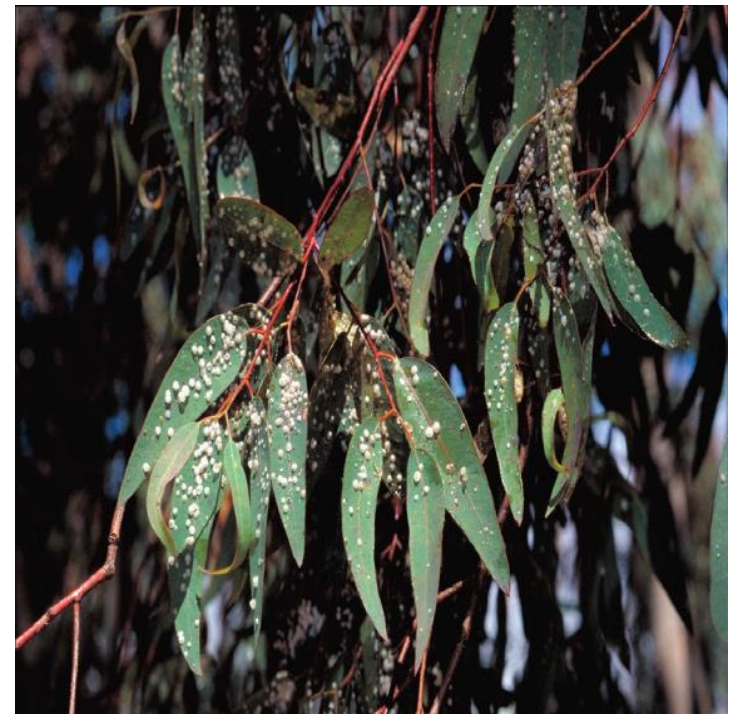

a

Damage to trees is caused when the developing larvae of Leptocybe invasa produce galls on the leaf midribs, petioles and twigs. The galls cause the twigs to split, destroying the cambium. Small circular holes indicating exit points of adults from pupae are common on the galls. Repeated attacks lead to loss of growth and vigour in susceptible trees. Severely attacked seedlings show gnarled appearance, stunted growth, lodging, dieback and eventually die (Mendel et al., 2004; Nyeko \& Nakabonge, 2008; Jhala, Patel \& Vaghela, 2010; Petro, 2015; de Souza et al., (2014).

Termites attack on both Eucalyptus species and $C$. lusitanica seedlings was associated with debarked shoots slightly above and below the base level and

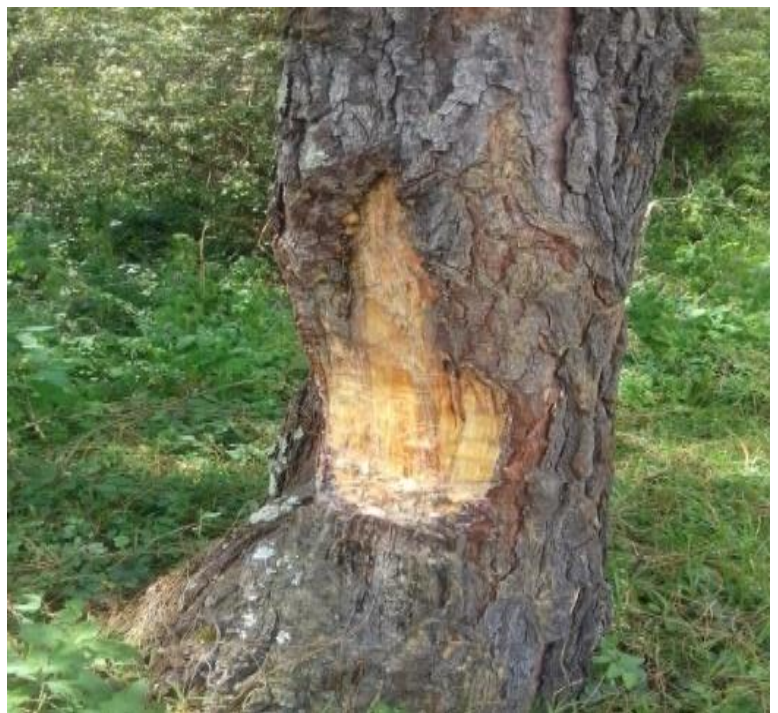

b

the presence of anti-hills around the tree nursery. Petro (2015) previously observed termites as a major pest of nursery seedlings and young plantation of Eucalyptus species below age five. Termites debark the stems below and slightly above ground level, thus affecting the functioning of the physiological process of plant structures, thus leading to the death of seedlings in the nursery (Nyeko \& Nakabonge, 2008). Other pests included humans, sap sacking Cinera cupressi and leaf defoliation caused by Pinus pini. These results are in agreement with the findings of Nyeko and Nakabonge (2008) and Gichora et al. (2017).

Major diseases in the Kimondi forest were identified by observing disease signs and symptoms. Results are presented in Table 6.

Table 6: Major Diseases Identified in Kimondi Forest

\begin{tabular}{lll}
\hline Disease & Observed Symptoms & Affected Tree Species \\
\hline Damping-off & Wilting, rotting stems, toppling or drying of stems & $\begin{array}{l}\text { Young seedlings of all } \\
\text { species }\end{array}$ \\
$\begin{array}{l}\text { Fusarium wilt } \\
\text { Botryosphaeria } \\
\text { canker }\end{array}$ & $\begin{array}{l}\text { Chloris of terminal needles wilted flaccid needles } \\
\text { Kino cracks, resin exudation, dieback on tips, } \\
\text { Cypress canker }\end{array}$ & $\begin{array}{l}\text { Coppice failure, fruiting bodies } \\
\text { Fruiting bodies, yellowing of needles, dieback, Cupressus lusitanica }\end{array}$ \\
Mycosphaerella sps & $\begin{array}{l}\text { oozing resin, stem lesion } \\
\text { Pale brown leaf margins }\end{array}$ & Eucalyptus \\
\hline
\end{tabular}


Damping-off disease associated with wilting and rotting stems was prevalent in young seedlings (Plate 2b). However, sometimes the yellowing and wilting of pine seedlings in some nurseries are associated with delayed pricking out, overstaying in the nursery or use of insufficient mycorrhizal soil
(Drenth \& Sendall, 2001), but this was never the case. Eucalyptus seedlings in the nursery as well as in the plantation displayed dieback and stem canker symptoms associated with Botryosphaeria infection (Plate 2a).

\section{Plate 2: a) Cracks, Kino and Resin Exudation on Eucalyptus Stem; b) Wilting of $C$. lusitanica Seedlings due to Damping Off Disease}

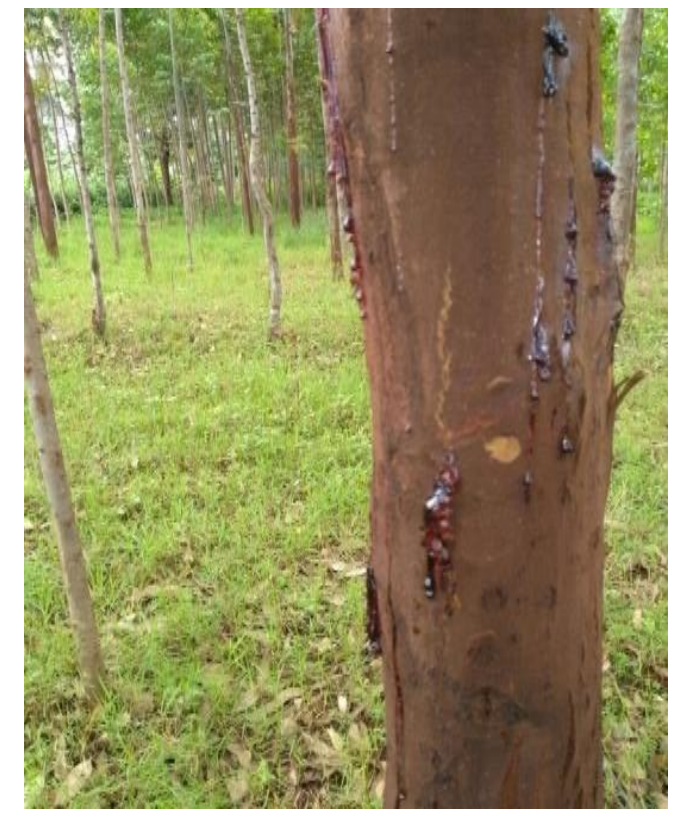

$\mathbf{a}$

Botryosphaeria infection was characterized by dieback of the growing tips, coppice failure and stem cankers. Old trees showed extensive kino accumulation, wood rot and fruiting bodies of Botryosphaeria spp. Cypress canker characterized by fruiting bodies on infected trees, yellowing of

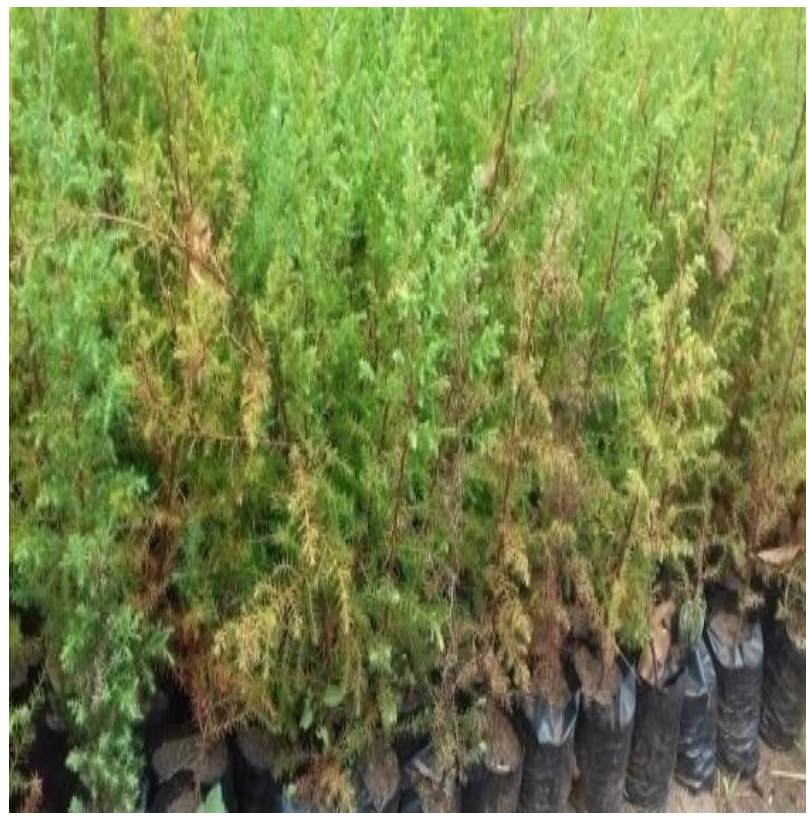

b needles, and dieback of branches, oozing resin, stem lesion and trunks were observed on $C$. lusitanica plantation. Mycosphaerella sps characterized by irregular pale, brown colouration on leaves with distinct red-brown leaf margin was observed (Plate $3 b)$. 
Plate 3: a) Stem Canker of C .lusitanica; b) Mycosphaerella Sps on Eucalyptus Leaves

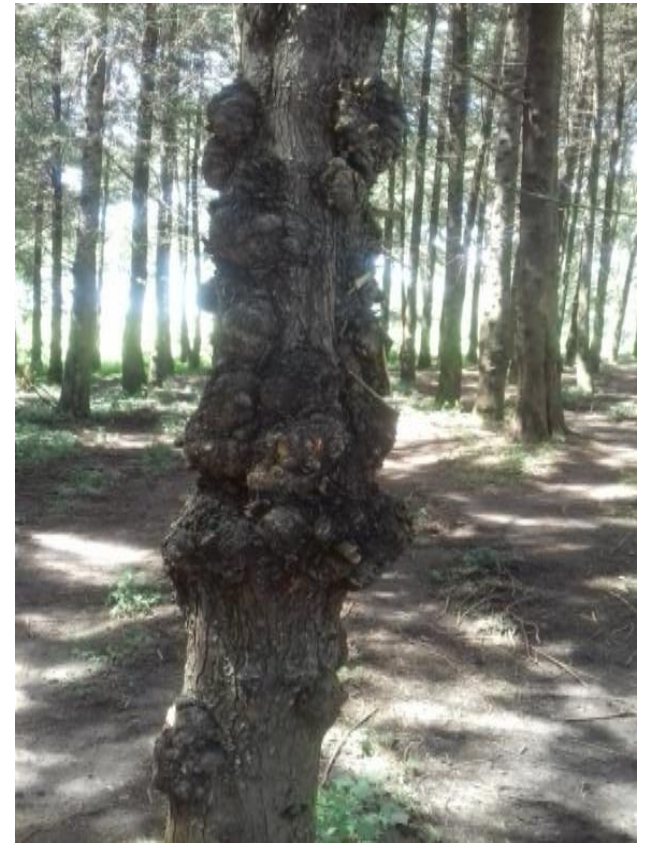

a

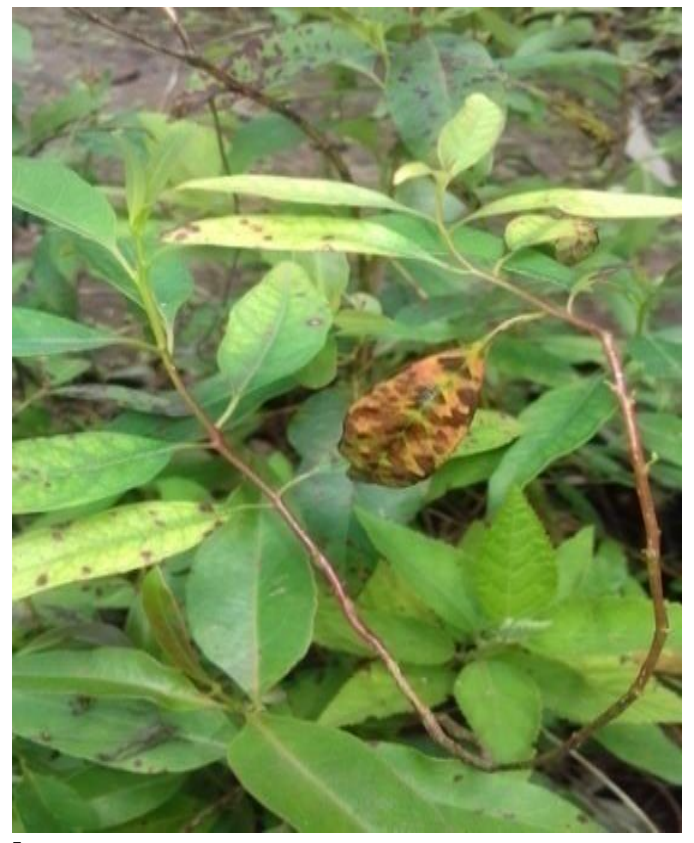

b

\section{CONCLUSION}

A high incidence of nursery seedling pests $(5.3 \%$ leaves and $5.1 \%$ stems) was observed on Eucalyptus species and least on P. patula $(2.4 \%$ leaves and 3\% stems). Higher incidence of plantation pests $(35.0 \%$ leaves of Eucalyptus sps.) and least on P. patula stems $(1.2 \%)$ were recorded. On the other hand, twelve $(12.0 \%)$ of $C$. lusitanica and (1.8\%) Eucalyptus species plantation twigs were infested by pests. A high incidence of nursery seedling disease (9.8\%) was observed on $C$. lusitanica leaves and least on $P$. patula stems (3.6\%). Higher incidence of plantation diseases $(32 \%)$ leaves of Eucalyptus sps. and least on C. lusitanica stem (1.4\%) was recorded. In both tree nurseries and plantations, roots and fruits remained free from pests and disease, respectively. Major tree pests and diseases identified in Kimondi forests include (Human, wildlife, livestock, Cinera cupressi, Gonipterus scutellatus, Pinus pini and Leptocybe invasa) and damping off, Fusarium wilt, Botryosphaeria canker, cypress canker and Mycospherella sps.) respectively. These results suggest a need for intervention measures to control pest and disease infestation in the Kimondi forest.

\section{REFERENCE}

Anonymous. (2006). Survey methodology for Bacterial blight of pomegranate, NCRP publication, pp. 14

Barnes, I., Crous, P. W., Wingfield, B. D., \& Wingfield, M. J. (2004). Multigene phylogenies reveal that red band needle blight of Pinus is caused by two distinct species of Dothistroma, D. septosporum and D. pini. Studies in Mycology, 50(2), 551-565.

Cock, M. J. W. (2003). Biosecurity and Forests: An introduction with particular emphasis on forest pests. Forest Health and Biosecurity Working paper FBS/2E. Rome, Italy: FAO.

Day, R. K., Kairo, M. T. K., Abraham, Y. J., Kfir, R., Murphy, S. T., \& Mutitu, K. E. (2003). Biological control of Homopteran pests of conifers in Africa. In Neuenschwander, P. Borgemeister, C. \& Langewald, J. (Eds), Biological control in IPM systems in Africa (pp. 101-112). CAB International, Wallingford, UK.

de Souza, M. D., Rezende, E. H., Alves, T., Bandeira, R. R., \& Fernandes, A. D. M. (2014). First report of Leptocybe invasa Fisher and 
LaSalle (Hymenoptera: Eulophidae) in Mozambique. African Journal of Agricultural Research, 9(49), 3555-3558.

Drenth, A., \& Sendall, B. (2001). Practical guide to detection and identification of Phytophthora. Tropical Plant Protection, 1, 3233.

Durán, A., Gryzenhout, M., Slippers, B., Ahumada, R., Rotella, A., Flores, F., ... \& Wingfield, M. J. (2008). Phytophthora pinifolia sp. nov. associated with a serious needle disease of Pinus radiata in Chile. Plant Pathology, 57(4), 715727.

European and Mediterranean Plant Protection Organization (EPPO). (2006). EPPO Alert List: Leptocybe invasa (Hymenoptera: Eulophidae)Blue Gum chalicid. Retrieved on $26^{\text {th }}$ March 2018 from http://www.eppo.org/QUARANTINE/Alert_Lis t/insects/Leptocybe invasa.htm.

Evans, J. (1992). Plantation forestry in the tropics: tree planting for industrial, social, environmental, and agroforestry purposes. Oxford University Press.

FAO. (2003). An illustrated guide to the state of health of trees Recognition and interpretation of symptoms and damage. Diagnostic and Advisory Service CABI Bioscience Egham, Surrey, United Kingdom

FAO. (2006). Global Forest Resources Assessment 2005 - progress towards sustainable forest management. Forestry Paper No. 147. Rome, Italy. Available at: http://www.fao.org/docrep/008/a0400e/a0400e0 o.htm

FAO. (2007). Forest Pest Species Profile: Heteropsyllacubana, Crawford, 1914. Rome: FAO. www.fao.org/forestry/13564-1-0.pdf

Gibson, I. A. S., Christensen, P. S., \& Munga, F. M. (1964). First observations in Kenya of a foliage disease of pines caused by Dothistroma pini Hulbary. The Commonwealth Forestry Review, $31-48$
Gibson, I.A.S. (1975). Diseases of forest trees widely planted as exotics in the tropics and southern hemisphere. Part 1, important members of the Myrtaceae, Leguminosae, Verbinaceae and Meliaceae. Commonwealth Mycological Institute and Forestry Institute. Kew and Oxford.

Gichora, M., Kojwang, H., \& Bosu, P. (2017). The status and trends of forest and tree pests and diseases management in Africa. African Forest Forum Working Papers (3)3. African Forest Forum, Nairobi.

GOK. (2008). Kenya Forest Service Board Paper: Revision of royalties for financial year 2008/09. Nairobi, KE: KFS.

Hurley, B. P., Slippers, B., \& Wingfield, M. J. (2007). A comparison of control results for the alien invasive woodwasp, Sirex noctilio, in the southern hemisphere. Agriculture Forest Entomology, 9, 159-171.

Jhala, R. C., Patel, M. G., \& Vaghela, N. M. (2010). Effectiveness of insecticides against blue gum chalcid, Leptocybe invasa Fisher \& La Salle (Hymenoptera: Eulophidae), infesting eucalyptus seedlings in middle Gujarat, India. Karnataka Journal of Agricultural Sciences, 23(1), 84-86.

Lundquist, J. E., Purnell, R. C., \& de Wet, D. R. (1987). Effects of Mycosphaerella leaf spot on the growth of Eucalyptus nitens. Plant Disease, 71(11), 1025-1029.

Mendel, Z., Protasov, A., Fisher, N., \& La Salle, J. (2004). Taxonomy and biology of Leptocybe invasa gen. \& sp. n.(Hymenoptera: Eulophidae), an invasive gall inducer on Eucalyptus. Australian Journal of Entomology, 43(2), 101-113.

Mitchell, N. (2004). Exploitation and disturbance history of Kakamega Forest, western Kenya. BIOTA East Report number 1

Murphy, S. T. (1998). Protecting Africa's trees. UNASYLVA-FAO-, 57-61. 
Mutitu, K. E. (2003). A pest threat to Eucalyptus species in Kenya. KEFRI Technical Report. Nairobi, KEFRI.

Nair, K. S. S. (ed.) (2000). Insect Pests and Diseases in Indonesian Forests: An Assessment of the Major Threats, Research Efforts and Literature. Bogor, Indonesia: Center for International Forestry Research.

Nsolomo, V. R., \& Venn, K. À. R. E. (1994). Forest fungal diseases of Tanzania: background and current status. Norwegian Journal of Agricultural Sciences, 8, 189-189.

Nyeko, P. \& Nakabonge, G. (2008). Occurrence of pests and diseases in tree Nurseries and plantations in Uganda. Kampala, Uganda: the Sawlog Production Grant Scheme (SPGS)

Nyeko, P. (2005). The cause, incidence and severity of a new gall damage on Eucalyptus species at Oruchinga refugee settlement in Mbarara district, Uganda. Uganda Journal of Agricultural Sciences, 11, 47-50.

Oballa, P. O., Konuche, P. K. A., Muchiri, M. N. and Kigomo, B. N. (2010). Facts on growing and use of Eucalyptus in Kenya. KEFRI, Nairobi, Kenya.

Otieno, N. E., Sajita, N., \& Shitandayi, D. (2014). Response of a globally endangered canopy insectivore to habitat degradation in an East African tropical rainforest: The role of differential forest protection levels. International Journal of Biodiversity and Conservation, 6(3), 290-300.

Petro, R. (2015). Effects of eucalyptus gall wasp, leptocybe invasa (Hymenoptera: eulophidae) on growth and wood basic density of some eucalyptus species, Tanzania. Doctoral Thesis, Sokoine University of Agriculture.

Simon, R. K., Kosgei, A. J., \& Kireger, E. (2016). Economic valuation of underutilized forestry Products in South Nandi Forest. International Journal of Research in Applied, Natural and Social Sciences. 4(8), 29-36.

Sokal, R. R., \& Rohlf, F. J. (2012). Biometry, 4th ed. New York. NY: WH Freeman and Company.
Tribe, G. D. (2003). Biological control of defoliating, and phloem- or wood-feeding insects in commercial forestry in southern Africa. . In Neuenschwander, P. Borgemeister, C. \& Langewald, J. (Eds), Biological control in IPM systems in Africa (pp. 113-129). CAB International, Wallingford, UK.

Wingfield, M. J., Slippers, B., Hurley, B. P., Coutinho, T. A., Wingfield, B. D., \& Roux, J. (2008). Eucalypt pests and diseases: growing threats to plantation productivity. Southern Forests: a Journal of Forest Science, 70(2), 139144.

Wingfield, M.J., Slippers, B., \& Wingfield, B.D. (2010). Novel associations between pathogens, insects and tree species threaten world forests. New Zealand Journal of Forest Sciences, 40, S95-S103.

Wingfield, M. J., Slippers, B., Roux, J., \& Wingfield, B. D. (2001). Worldwide movement of exotic forest fungi, especially in the tropics and the southern hemisphere: This article examines the impact of fungal pathogens introduced in plantation forestry. Bioscience, 51(2), 134-140. 